\title{
Advanced high strength steels for automotive industry $(\cdot)$
}

\author{
J. Galán*, L. Samek", P. Verleysen*, K. Verbeken* and Y. Houbaert ${ }^{*}$
}

\begin{abstract}
The car industry is facing pressure because of the growing demand for more fuel-efficient passenger cars. In order to limit energy consumption and air pollution the weight of the carbody has to be reduced. At the same time, high levels of safety have to be guaranteed. In this situation, the choice of material becomes a key decision in car design. As a response to the requirements of the automotive sector, high strength steels and advanced high strength steels have been developed by the steel industry. These modern steel grades offer an excellent balance of low cost, light weight and mechanical properties.
\end{abstract}

Keywords

\section{Aceros avanzados de alta resistencia en la industria automovilística}

Resumen

Palabras clave

\begin{abstract}
La industria del automóvil se enfrenta a una creciente demanda de vehículos de pasajeros más eficientes. Con el fin de disminuir el consumo de energía y la contaminación ambiental, el peso del vehículo tiene que ser reducido, al mismo tiempo que se garantizan altos niveles de seguridad. Ante esta situación, la elección de material se convierte en una decisión crucial en el diseño del vehículo. Como respuesta a las necesidades del sector automovilístico, nuevos aceros avanzados y de alta resistencia, han sido desarrollados por la industria siderúrgica. Dichos tipos de acero ofrecen un excelente equilibrio de precio, peso y propiedades mecánicas.
\end{abstract}

Acero; Aceros de alta resistencia; Aceros avanzados de alta resistencia; Aceros de baja aleación; TRIP.

\section{INTRODUCTION}

Vehicle designers must balance the objectives of better fuel economy, crash safety standards imposed by the government and stringent consumer demands. Reducing the weight of a vehicle is a straightforward strategy to improve fuel economy, but it can potentially create safety problems. As a matter of fact, although a weight reduction of $\sim 10 \%$ on the total vehicle weight was estimated to result in $5.5 \%$ improvements in fuel economy ${ }^{[1]}$, the average weight of the passenger car is continuously increasing as a consequence of the introduction of new security systems, such as air bags and anti-block systems.

The body-in-white (BIW) structural parts and panels, and in particular the materials used in its construction, offer the greatest possibilities in terms of weight reduction and determine the behaviour of the car in the event of collisions. In addition to low weight and good mechanical behaviour high levels of formability, joinability, weldability and paintability are important points to have a competitive material.

In an attempt to respond to the demands of the automotive sector, the steel industry has developed new high strength steels (HSS) and advanced high strength steels (AHSS) with a better balance of low cost, light weight and mechanical properties ${ }^{[2]}$.

This paper offers an overview of the new steel grades used by the automotive industry. First, the material requirements of the car industry are discussed, as well as the response of the steel producers in the form of the ULSAB and ULSAB-AVC programs. The different high strength steel grades developed for the construction of carbodies are further explained along the next sections, with special emphasis on low alloy and transformation-induced plasticity (TRIP) steels. Finally, the main conclusions are compiled in the summary.

(.) Trabajo recibido el día 10 de octubre de 2011 y aceptado en su forma final el día 07 de febrero de 2012.

* Department of Materials Science and Engineering, Ghent University Technologiepark Zwijnaarde 903, 9052 Zwijnaarde, Belgium.

E-mail: jesus.galanlopez@ugent.be 


\section{MATERIAL REQUIREMENTS IN CARBODY DESIGN: FUEL EFFICIENCY VERSUS SAFETY}

\subsection{Fuel efficiency}

More fuel-efficient passenger cars are required to reduce energy consumption and air pollution. On the one hand, fuel consumption of the average car has to decrease significantly to satisfy the demand of the ever growing car population while the availability of fuel continuously decreases ${ }^{[3]}$. On the other hand, $\mathrm{CO}_{2}$ and other greenhouse gas emissions need to be reduced by 60-80 percent in the decades to come from their 2005 levels to avoid too high concentrations in the atmosphere that would adversely affect climate change.

The transportation sector was reported to be responsible for over half of the world's oil consumption and $\sim 30 \%$ of the total energy consumption $^{[4]}$. It has been estimated that $\sim 70 \%$ of this energy was spent on effective driving, $\sim 16 \%$ to produce the raw materials, $\sim 9 \%$ for the industrial production and only $1 \%$ for disposal and recycling ${ }^{[2]}$.

In order to reduce this energy consumption possible measures to be taken include: changes in driving style, reduction of tire resistance, better engines and gear components and, last but not least, vehicle weight reduction ${ }^{[5]}$.

\subsection{Crash safety}

In a crash event, a well designed vehicle should be able to absorb the impact energy effectively. This requirement conflicts with the need for lighter vehicles. Indeed, published studies on the effect of the reduction of the average weight of passenger cars on the frequency and severity of crash incidents have shown that a reduction of $500 \mathrm{~kg}$ in car weight increased by 2000 the number of fatalities and by 20000 the serious injuries (per year and on the base of the same materials and technologies $)^{[6]}$. Research showed that, for a given automotive crash, larger vehicles provide more occupant protection independent of the mass ${ }^{[7]}$. In general, in the case of a crash between a light and a heavy vehicle, the heavier one will give a better safety performance.

Standard tests for safety in new passenger vehicles are defined by the Euro-NCAP and the US-NCAP (where NCAP stands for New Car Assessment Programme). There are also tests run by organizations backed by the insurance industry, such as the International Institute of Health Studies (IIHS). The stringent crash safety ratings are carried out by NorthAmerican and E.U. regulations by means of simulated crash events. In these simulations, the protection of occupants for different car designs and crash conditions is evaluated.

The current Euro-NCAP Offset Deformable Barrier (ODB) test (Fig. 1) replaces the 20-year old frontal impact test. The problem with the frontal test, which involved a full width frontal impact against a solid concrete barrier, was that it did not reflect the specific collisions between two cars. Most frontal car collisions tend to pierce the softer surrounding structure and transmit the energy to other parts of the vehicle. The new Euro-NCAP ODB test is a simulation of both the partial overlap of typical frontal collisions and the real frontal structure of a typical car, by using a deformable impact surface and a $40 \%$

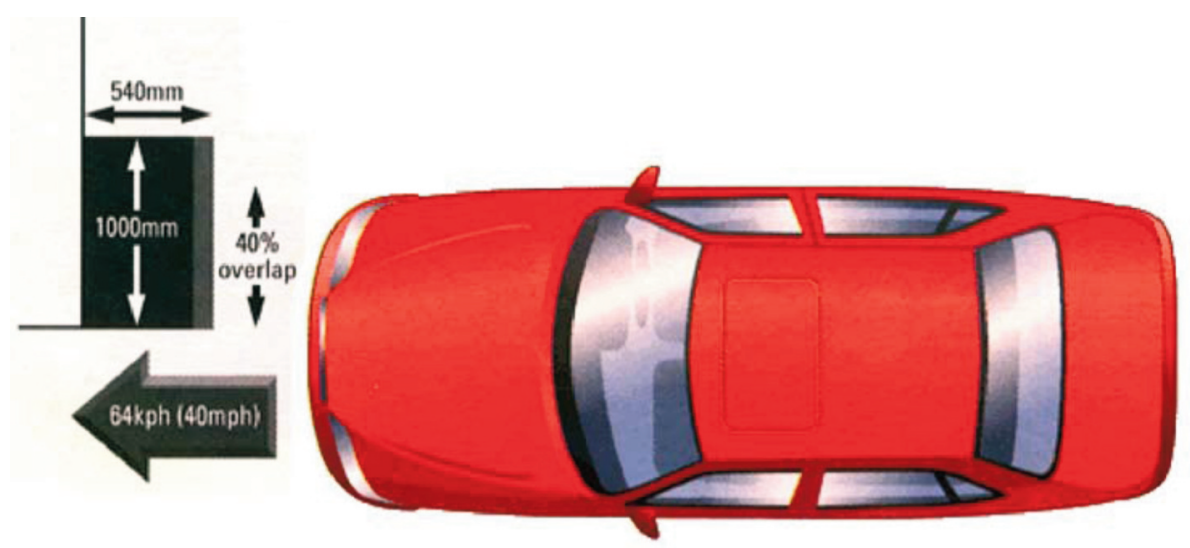

Figure 1. Euro-NCAP experimental setup for testing car crash resistance to a frontal impact with $40 \%$ offset.

Figura 1. Instalación experimental Euro-NCAP para ensayar la resistencia del vehículo a un impacto frontal con un desfase del $40 \%$. 
impact offset. Readings taken from crash dummies are used to assess protection to front occupants and to rate the safety of different car designs.

\section{IMPORTANCE OF HIGH STRENGTH STEELS IN LIGHTWEIGHT CARBODY DESIGN}

High strength steel grades, ultra high strength steel grades and advanced high strength steels grades have been specifically developed to satisfy the demand of the car industry. These new steel grades have already proven their superiority to meet the requirements for automotive materials: durability, strength, stiffness, good crash energy absorption and acoustic properties, low production cost in high quantities and possibility of recycling ${ }^{[2]}$.

Considering a safety based car body design, two main types of high strength steels are intensively used:

- high strength steel grades with a high energy absorption potential, typically dual phase (DP) and TRIP steel grades with tensile strength $<1000 \mathrm{MPa}$, for dynamic loading occurring during car crashes or collisions;

- high strength steels with a tensile strength $>1200 \mathrm{MPa}$, typically martensitic steel grades, which provide a high stiffness, anti-intrusion barrier for the protection of passengers.

The most striking example of the application of HSS to car body design is the development of the ULSAB and ULSAB-AVC programs, described in the next section.

\subsection{ULSAB and ULSAB-AVC programs}

In 1994, an international consortium of sheet steel producers comprised of 35 companies from 18 countries started the Ultra Light Steel Auto Body project (ULSAB) to explore opportunities for weight saving in automotive components. The engineering study resulted in the development of a steel auto body with a $90 \%$ of HSS. The new car body had $25 \%$ less mass and $14 \%$ less cost than benchmarked four door sedans. Furthermore, the torsion stiffness was improved by $80 \%$ and the bending stiffness by $52 \%{ }^{[8]}$.

The Ultra Light Steel Auto Body-Advanced Vehicle Concept (ULSAB-AVC) is the latest evolution of the ULSAB concept. The ULSAB-AVC program focused on further increasing energy efficiency and passenger safety, high volume manufacturability at affordable cost and minimal impact on the environment.

Advanced high strength steels were the key factor in order to achieve the results from the ULSAB-AVC program: the ULSAB-AVC body structure consists of a $100 \%$ of HSS, with over $80 \%$ being AHSS grades ${ }^{[9]}$. These steel grades were selected from an international catalogue compiled from data supplied by member companies.

\subsection{High strength steel grades}

HSS are defined as steels with yield strength from 210 to $550 \mathrm{MPa}$. Ultra high strength steels (UHSS) reach yield strengths above $550 \mathrm{MPa}$. The HSS grades include interstitial free (IF), bake hardenable (BH), carbon-manganese (C-Mn) and high strength low alloy (HSLA) steels. Typical HSS mechanical properties are listed in table I.

AHSS are flat steel products with a strengthductility balance superior to conventional steel grades. Members of the AHSS family are the DP, complex phase (CP), TRIP, bainitic and martensitic steels. The principal difference between conventional HSS and AHSS is their microstructure: AHSS are multiphase steels, which may contain polygonal ferrite, bainitic ferrite, retained austenite, stress/strain-induced martensite and athermal martensite. The transformation of retained austenite into martensite during deformation provokes the so-called TRIP effect ${ }^{[11]}$. Additionally,

Table I. Typical high strength steel grade mechanical properties[10]

Tabla I. Propiedades mecánicas típicas de los aceros de alta resistencia[10]

\begin{tabular}{lccc}
\hline \multicolumn{1}{c}{ Product } & Yield strength, MPa & Tensile strength, MPa & Elongation, \% \\
\hline HSS, hot rolled & $310-462$ & $380-558$ & $26-28$ \\
HSS, cold rolled & $303-370$ & $372-445$ & $26-27$ \\
HSLA & $300-420$ & $384-500$ & $27-36$ \\
\hline
\end{tabular}




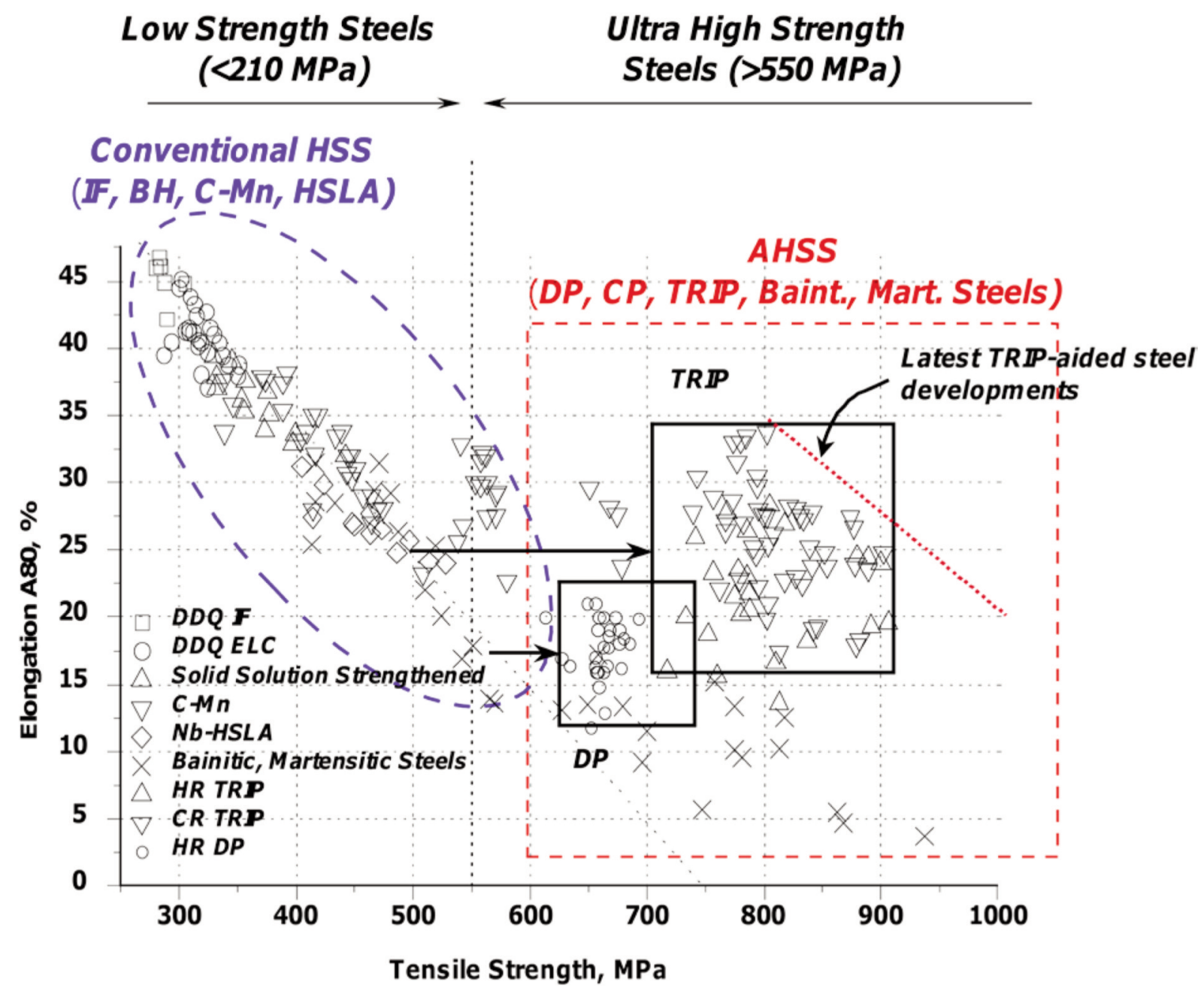

Figure 2. Tensile strength versus elongation for conventional HSS and advanced HSS steels.

Figura 2. Resistencia a tensión en función de la elongación en aceros de alta resistencia convencionales y avanzados.

(micro) alloying can be used to provide further strength, while maintaining good ductility ${ }^{[12 \text { and } 13]}$. This practice is common in the case of TRIP steels. Figure 2 shows the tensile strength versus elongation for conventional HSS and AHSS steels.

\section{High strength steel for automotive applications}

The development of high strength steels for the automotive industry began in the 1970's with the development of low carbon steels, followed by DP and bake hardening steels in the 1980's and TRIP steels and their micro-alloying concept in the 1990's. In more recent years, the complex phase and martensite phase ultra high strength steels have been introduced. Figure 3 shows a schematic representation of the history of high strength steels development.

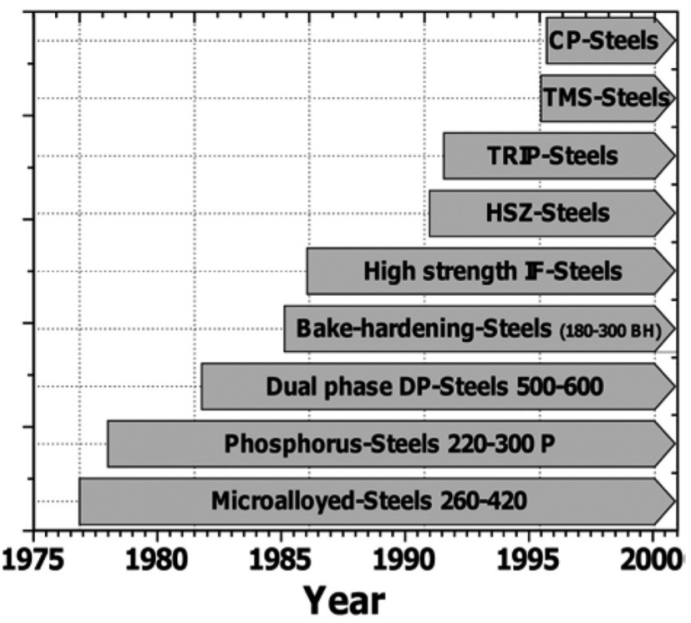

Figure 3. Development over time of high strength steels for automotive applications ${ }^{[14]}$.

Figura 3. Desarrollo histórico de los aceros de alta resistencia de uso automovilístico[14]. 
The tailored combination of soft and hard phases, and the presence of metastable austenite in the case of retained austenite (RA) steels, gives to the AHSS grades the superior strength-ductility balance demanded by the car industry. These improved properties allow the usage of thinner parts, with the consequent reduction of weight. However, for about $80 \%$ of all body parts, the reduction of sheet thickness is limited by the required stiffness. Furthermore, the reduction of sheet thickness tends to deteriorate the dent resistance of pressed panels. To improve dent resistance - as well as formability - of AHSS, bakehardenable high strength steels were developed ${ }^{[15]}$. $\mathrm{BH}$ steels offer superior dent resistance and, therefore, a higher potential for thickness reduction. This characteristic is particularly important for parts which exhibit slight deformation, or no deformation at all, in individual areas such as roofs, bonnets or tailgates.

Figure 4 schematically reviews the material requirements for passenger cars and the most suitable steels. Due to their higher formability, while maintaining comparable yield stress and significantly improved tensile strength, DP and TRIP steels show the greatest production increase $\mathrm{e}^{[9,16}$ and 17] .

The demand for dual phase grades for automotive applications is significantly and continuously increasing ${ }^{[9,14}$ and 17$]$, especially in the case of hot band steel for the inner parts and the wheels of the car ${ }^{[18]}$. The replacement of standard steel (ST14 and BH180) with DP grades in the ULSAB-AVC design resulted in weight reductions for body panels of $13 \%$ and $21 \%{ }^{[16]}$. DP steel accounts for $75 \%$ of the total sheet material used in the ULSAB-AVC body.

TRIP steel is the first choice material for superior crash behaviour. It offers, with thinner panel thickness, superior mechanical properties for parts exposed to high stresses and very high strain rate deformations, such as bumper bars, impact beams, B-pillar and reinforcements. TRIP steel shows an excellent dent resistance with reduced sheet thickness, perfectly suited for the automotive outer body panels with exigent performance requirements ${ }^{[19]}$. In the ULSAB-AVC carbody $4 \%$ of the total BIW weight consists of TRIP steel.

Nevertheless, there are limiting factors for the broad application of high strength steel sheets. The addition of expensive alloying elements rises the production costs, hot dip zinc coated steel sheets (particularly when alloyed with silicon) exhibit coating problems and it is possible to find formability difficulties like necking, wrinkles and springback, as well as welding complications.

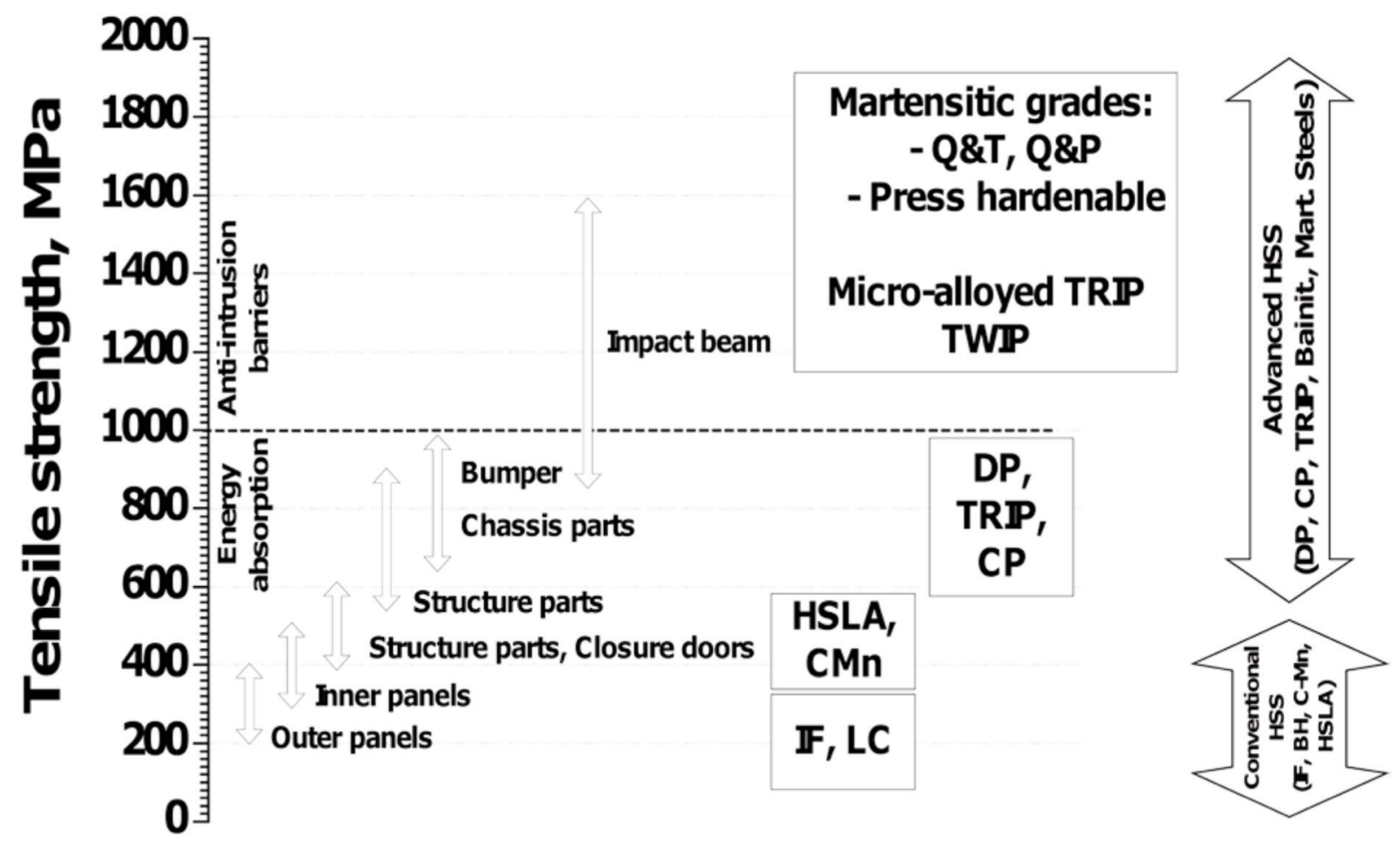

Figure 4. Tensile strength requirements of different components of passenger cars and range of application of $\mathrm{HSS}^{[9,16}$ and 17$]$.

Figura 4. Resistencia a tensión requerida por diferentes componentes de coches de pasajeros y campo de aplicación de los aceros de alta resistencia ${ }^{[9,16}$ y 17]. 
In the next sections, low-alloy high strength steel grades are further discussed, with emphasis in the TRIP-aided steels for its importance for the automotive industry.

\subsubsection{Low-alloy high strength steel}

The first steels developed for automotive applications were the low carbon (LC) and extra low carbon (ELC) steels. They offer improved forming characteristics and are significantly cost effective. The microstructure of low carbon steel consists of large polygonal ferritic grains, obtained applying the thermal treatment presented in figure 5. Low carbon steel can be used for most automotive parts, from small flat parts to large deep drawn parts, such as floor pans, and its low carbon content (C 200 wt.-ppm) makes them suitable for typical automotive welding techniques. However, the use of these steels may be limited by its relatively low yield strength, especially considering the increasing requirements of dent resistance. Bake hardenable, low carbon deep drawing steel grades were developed to solve these problems. These steels present a hardening effect during the baking of the paint.

Later on, ultra low carbon steels (ULC) were developed. The amount of carbon in these steels is limited to a concentration of $50 \mathrm{wt}$.-ppm. Ultra

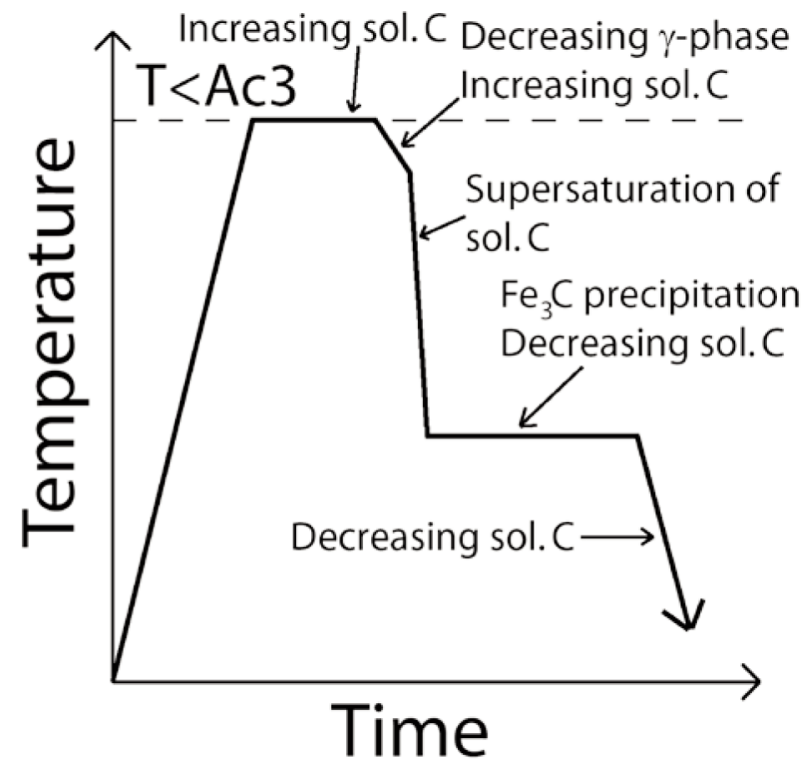

Figure 5. Typical thermal treatment to obtain LC steel grades ( 200ppm C).

Figura 5. Tratamiento térmico típico para obtener tipos de acero con bajo contenido de carbono ( 200ppm C). low carbon steels are single phase ferritic steels with a very low content of alloying elements. The microstructure differs significantly from the low carbon steels, which contain inter and intragranular carbides. ULC steels are being increasingly used to manufacture outer carbody parts. Higher strength and improved dent resistance capacities have been developed with bake hardenable ultra low carbon steels, in order to fulfil the requirements for thinner sheet steel for automotive applications. Typically up to $50-55 \mathrm{MPa}$ of yield strength increase may be obtained during the paint baking process. The ULC-BH steels exhibit typically 200-280 MPa of yield strength with $30-47 \%$ of elongation.

Low-alloyed multiphase steels have a complex microstructure, consisting of an adequate mixture of the following phases: ferrite, bainitic ferrite, retained austenite and martensite. Each phase contributes to the overall behaviour of the material in different ways.

Cold rolled complex phase steels have a microstructure of martensite and/or bainite in a matrix of ferrite and/or strengthened ferrite. The strengthening of the ferrite matrix is caused by a high dislocation density or precipitation of microalloying elements. CP steels exhibit significant higher yield strength than DP steels, with comparable tensile strengths.

DP steels have a microstructure consisting of a soft ferrite matrix and a medium carbon lath type martensite second phase, with a content varying from 5 to 50 vol.- $\%$. The amount of martensite determines the strength of the steel. To produce dual phase steels, a two stage thermal cycle is used consisting of an intercritical annealing followed by a fast cooling to promote the transformation of the intercritical austenite to martensite (see figure 6). DP steels exhibit a low yield strength ratio and high work hardening ${ }^{[20]}$. An excellent strength-ductility balance is obtained when martensite constitutes a dispersed second phase in the ferrite matrix, when its volume fraction is around $10-20 \%$.

One of the particularities of DP steels is their continuous yielding. This property is due to the presence of internal stresses which allow dislocations to remain mobile, i.e. not pinned by interstitial solute carbon atoms. During the austenite to martensite transformation, the volume expansion produces local plastic deformation of the ferrite. As a result, high mobile dislocation density and residual stresses are generated in the ferrite phase surrounding the martensite particles. Table II lists typical mechanical properties for industrially produced dual phase steels: the yield strength, tensile strength and maximum of uniform elongation $\mathrm{A}_{80}$. 


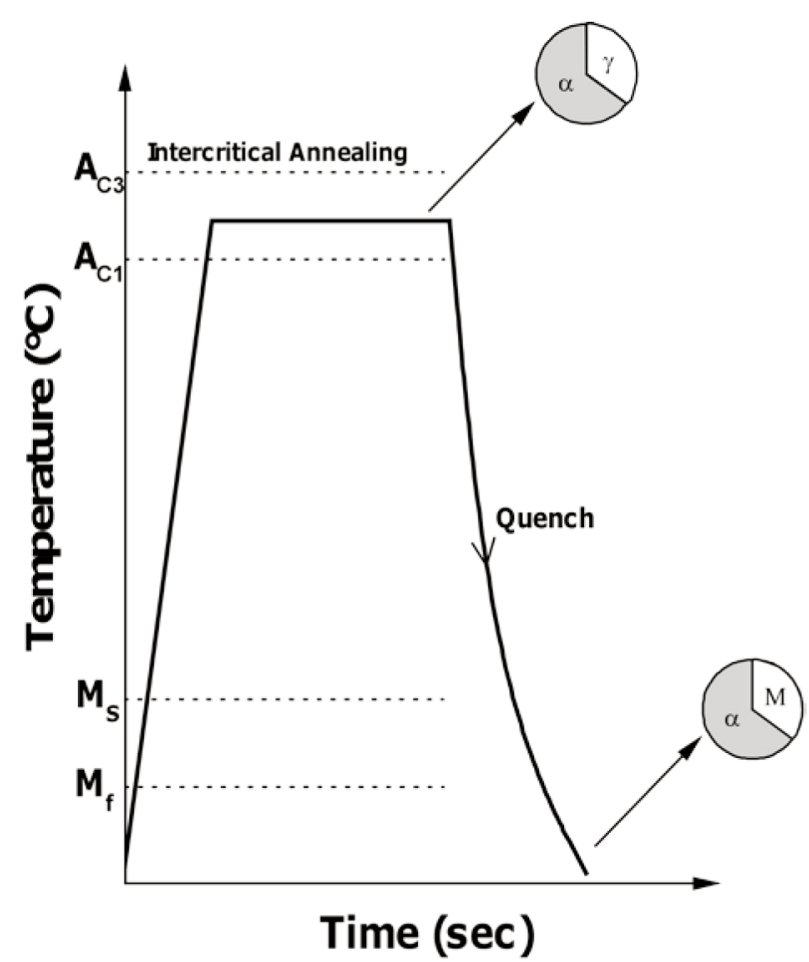

Figure 6. Intercritical annealing treatment used to process cold rolled dual phase steels in a Continuous Annealing (CA) line.

Figure 6. Recocido intercrítico usado como tratamiento en el proceso de aceros de fase dual en una línea de recocido continuo.

Low carbon dual phase sheet steel showing the TRIP effect has been developed for automotive applications ${ }^{[21-24]}$. Microstructures with morphologies and volume fraction of the different phases were investigated in order to enhance the mechanical properties ${ }^{[25-27]}$. Low alloy, high strength TRIP-aided steels are exciting materials developed by the steel industry thanks to their high tensile strength and their high uniform elongation ${ }^{[21,28-35]}$. TRIP steels have a complex microstructure, composed of different phases: ferrite ( 50 vol.- $\%)$, bainite ( 35-40 vol.- $\%)$, and retained austenite $(\sim 10-15$ vol.- $\%)$. TRIP steel will be discussed in more detail in the next section.
L-IP steels (light steels with induced plasticity) were recently developed by the steel industry in order to achieve a better strength-ductility balance, with use of strain-induced twinning and very high work hardening ${ }^{[36]}$. Ultra high strength steels were also developed, typically martensitic steel (MS), e.g. MS-1200. MS steels are currently being further developed to achieve improved formability for automotive applications.

Figure 7 present LOM (Light Optical Microscopy) and SEM (Scanning Electron Microscope) pictures of the typical microstructures of ULC, DP, TRIP, CP and martensitic steels, which were presented above.

\subsubsection{Low alloy high strength TRIP-aided steel}

Low alloyed multiphase high strength TRIP-aided steels combine high strength and good formability ${ }^{[21,28-35]}$. The retained austenite plays a major role in the superior mechanical properties in multiphase steels ${ }^{[30,37}$ and 38$]$, thanks to the TRIP effect. The TRIP effect, firstly described and investigated by Zackay et al. ${ }^{[11]}$ to enhance the ductility of high strength steels, is the transformation of the retained austenite to straininduced martensite during plastic deformation. The strain-induced plasticity permits the increase of the strain hardening rate, and hence indeed contributes to the improved ductility in high-strength steels containing metastable austenite ${ }^{[11,39-41]}$.

To obtain TRIP steel with an adequate amount of sufficiently stabilized retained austenite in its microstructure, a specific thermal processing of the cold rolled steel is required. Such a process is shown in figure 8 . The microstructure of the cold rolled material consists of a heavily deformed $50 \%$ ferrite-50\% pearlite phase mixture when a cooling temperature close to $600^{\circ} \mathrm{C}$ is used after hot rolling. In a first stage the strip is heated to a temperature in the intercritical + - region and held there for a short period of time, allowing the recrystallization of the deformed microstructure, dissolution of pearlite and

Table II. Mechanical properties of dual phase steel grades ${ }^{[18]}$

Tabla II. Propiedades mecánicas de tipos de acero de doble fase ${ }^{[18]}$

\begin{tabular}{cccc}
\hline Product & Yield strength, MPa & Tensile strength, MPa & $\mathbf{A}_{\mathbf{8 0}}, \boldsymbol{\%}$ \\
\hline DP 375/600 & 375 & 600 & $\geq 24$ \\
DP 400/700 & 400 & 700 & $\geq 14$ \\
DP 700/1000 & 700 & 1000 & $\geq 10$ \\
\hline
\end{tabular}



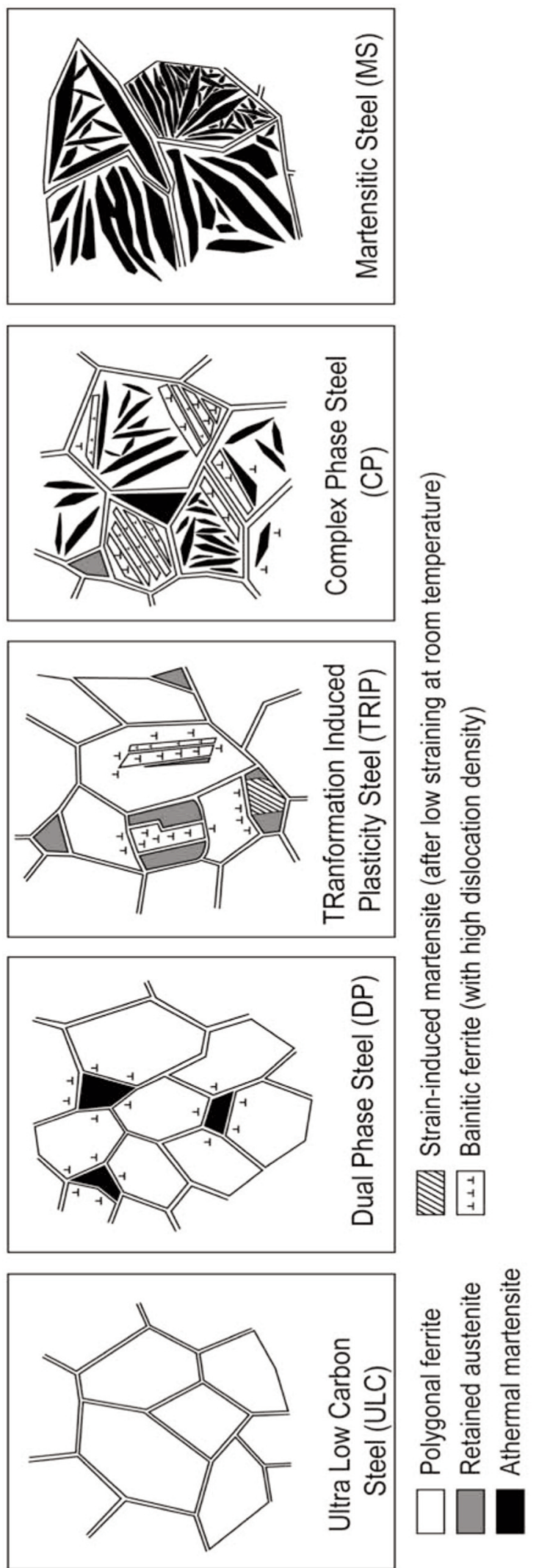
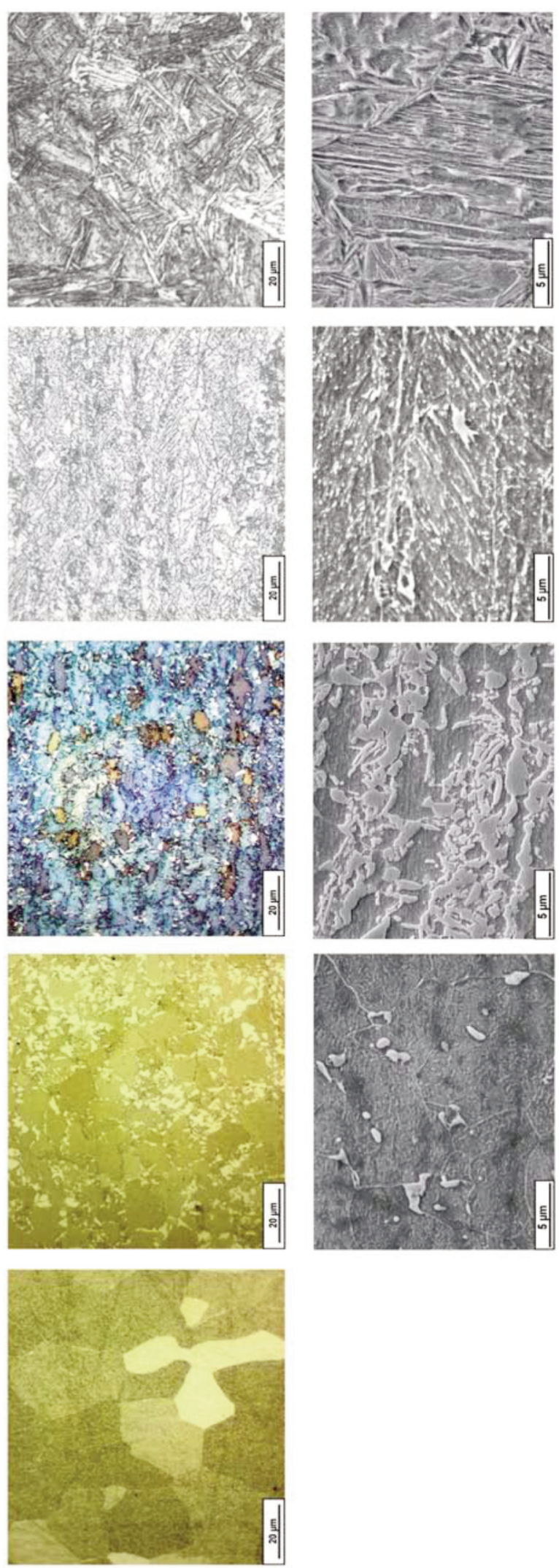

พOา

Figure 7. ULC (grade 557429), DP, TRIP, CP and martensitic steel microstructures represented by a schematic and compared by means of LOM and SEM techniques.

Figura 7. Microestructura de aceros ULC (tipo 557429), DP, TRIP, CP y martensíticos representada por un esquema y comparada por medio de técnicas LOM y SEM. 


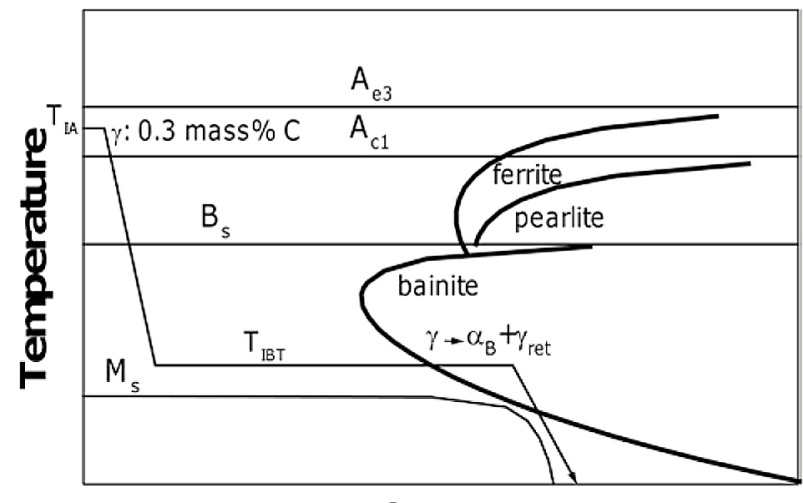

Time

Figure 8. Thermal processing route of cold rolled TRIP-aided steel[ ${ }^{[41]}$.

Figura 8. Ruta de procesamiento térmico de acero con efecto TRIP laminado en frío[41].

formation of a sufficient fraction of intercritical austenite. The annealing temperature chosen determines both the austenite volume fraction and its carbon concentration at the end of the intercritical annealing. Although the exact phase mixture may vary to some extent, an austenite carbon concentration in the range of $0.3 \mathrm{wt}$. $\%-0.4 \mathrm{wt}$. $\%$ is typically obtained. This concentration is however insufficient to stabilize austenite at room temperature. A second stage, consisting of a rapid cooling to a temperature in the bainitic transformation range and an isothermal hold, are therefore required.

It is important to use sufficiently high cooling rates between the intercritical annealing temperature $T_{I A}$ and the isothermal bainitic transformation temperature $\mathrm{T}_{\mathrm{IBT}}$ to avoid the formation of pearlite. This would lead to a decrease in austenite carbon concentration and a reduction in austenite stability. A minimum cooling rate of about $20^{\circ} \mathrm{C} / \mathrm{s}$ is necessary.

During the isothermal holding period austenite transforms into a low carbon bainite, resulting in further carbon enrichment of the remaining austenite. This process continues until the carbon concentration of the remaining austenite phase becomes equal to the value determined the temperature at which the Gibbs free energy of ferrite equals the Gibbs free energy of austenite of equal composition. At the start of the isothermal bainitic transformation the free energy of ferrite is lower than the free energy of austenite, which provides the necessary driving force for the diffusionless bainitic transformation. Due to the presence of Si or other carbide-suppressing elements such as $\mathrm{Al}$ and $\mathrm{P}, \mathrm{C}$ is expelled from the bainite into the austenite phase. As a result, the carbon content of the remaining austenite increases.
In terms of transformation plasticity of TRIP steels, four temperature ranges are important (Figure 9):

- Below the $\mathrm{M}_{\mathrm{s}}$ temperature: the austenite phase is thermodynamically unstable and the martensitic transformation will occur without any need of deformation.

$-M_{s}-M_{s}$ range: yielding of the austenite by stress-induced transformation of austenite to martensite at pre-existing nucleation sites. The chemical driving force decreases linearly with increase of temperature above $\mathrm{M}_{\mathrm{s}}$. The critical applied stress for the start of martensite transformation increases linearly with the temperature. At $M_{s}$, the stress needed to initiate the martensitic transformation of the retained austenite equals the yield strength of the parent austenite phase. Below this temperature, the retained austenite transforms to martensite via pre-existing nucleation sites.

- $M_{s}-M_{d}$ range: above the $M_{s}$ temperature, the austenite is strained. The martensite is predominantly nucleated at new nucleation sites produced by slip. It is noteworthy that this martensite is not of the high carbon plate type and will not have the brittleness associated with plate type martensite. Yielding of the austenite is by glide. The transformation is mainly strain-induced. Additional nucleation occurs at the intersection of straininduced deformation bands.

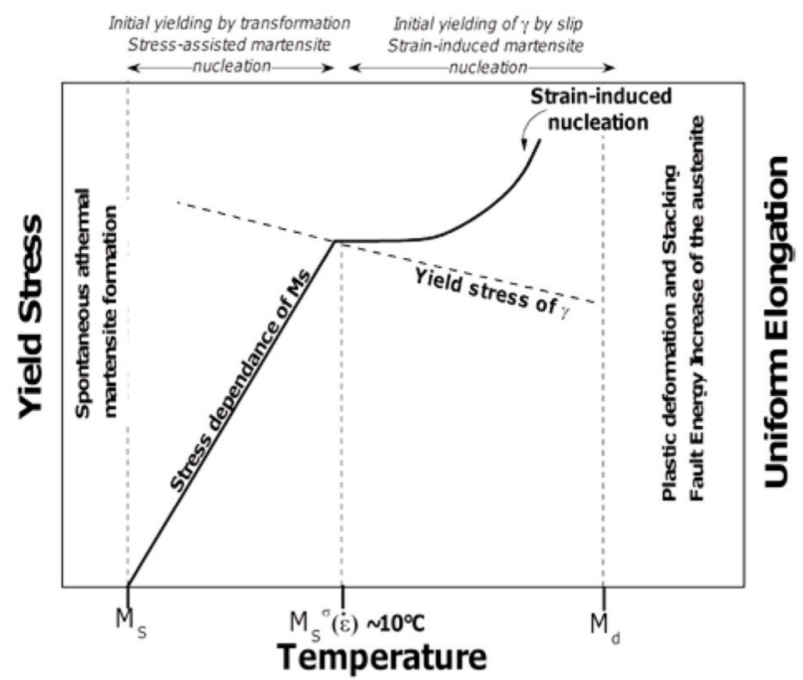

Figure 9. Stress-assisted and strain-induced regimes of mechanically induced martensitic transformation.

Figura 9. Tipos de transformación martensítica inducida por tension y deformación. 
ADVANCED HIGH STRENGTH STEELS FOR AUTOMOTIVE INDUSTRY ACEROS AVANZADOS DE ALTA RESISTENCIA EN LA INDUSTRIA AUTOMOVILISTICA

- $\mathrm{T}>\mathrm{M}_{\mathrm{d}}$ : the $\mathrm{M}_{\mathrm{d}}$ temperature is the temperature above which no martensite transformation occurs. The higher temperature results in a higher stacking fault energy and a lower driving force for transformation; no transformation occurs as a result of straining.

Figure 10 reviews the dominant deformation mechanisms in different temperature ranges in the retained austenite in TRIP steel.

A new processing method, "quenching and partitioning" (Q\&P) has been recently proposed to create steel microstructures with retained austenite. This process consists on quenching austenite below the martensite-start temperature, followed by a partitioning treatment to enrich the remaining austenite with carbon, thereby stabilizing it to room temperature ${ }^{[42-44]}$.

Many authors ${ }^{[24,29,30 \text { and } 45-47]}$ reported optimal mechanical properties for TRIP steels containing retained austenite with a volume fraction in the range of $8 \%-15 \%$. The stability of the retained austenite depends on several parameters: the chemical composition of the retained austenite and its intrinsic stacking fault energy (ISFE) ${ }^{[45]}$, the reduction of the size of the retained austenite (which is a crucial stabilization factor $)^{[46 \text { and } 48]}$, the stress state ${ }^{[41 \text { and } 47]}$, the strength of the austenite and the presence of other phases in its vicinity ${ }^{[47]}$ and the morphology and distribution of retained austenite in the microstructure ${ }^{[25-27]}$.

The superior mechanical properties during high strain rate tests exhibited by low alloy, TRIP steels, is the result of both the composite effect of the different phases and the transformation ${ }^{[35]}$. Figure 11 illustrates this by comparing the mechanical properties of a high strength interstitial free steel (HS IF) with those of a TRIP steel. In quasi-static loading, the TRIP-aided steel has both a higher tensile strength and a higher uniform elongation.

Whereas static tensile tests are isothermal, dynamic testing conditions are adiabatic. Figure 11 shows the effect of the adiabatic heating of a soft IF steel in dynamic loading: thermal softening prevails

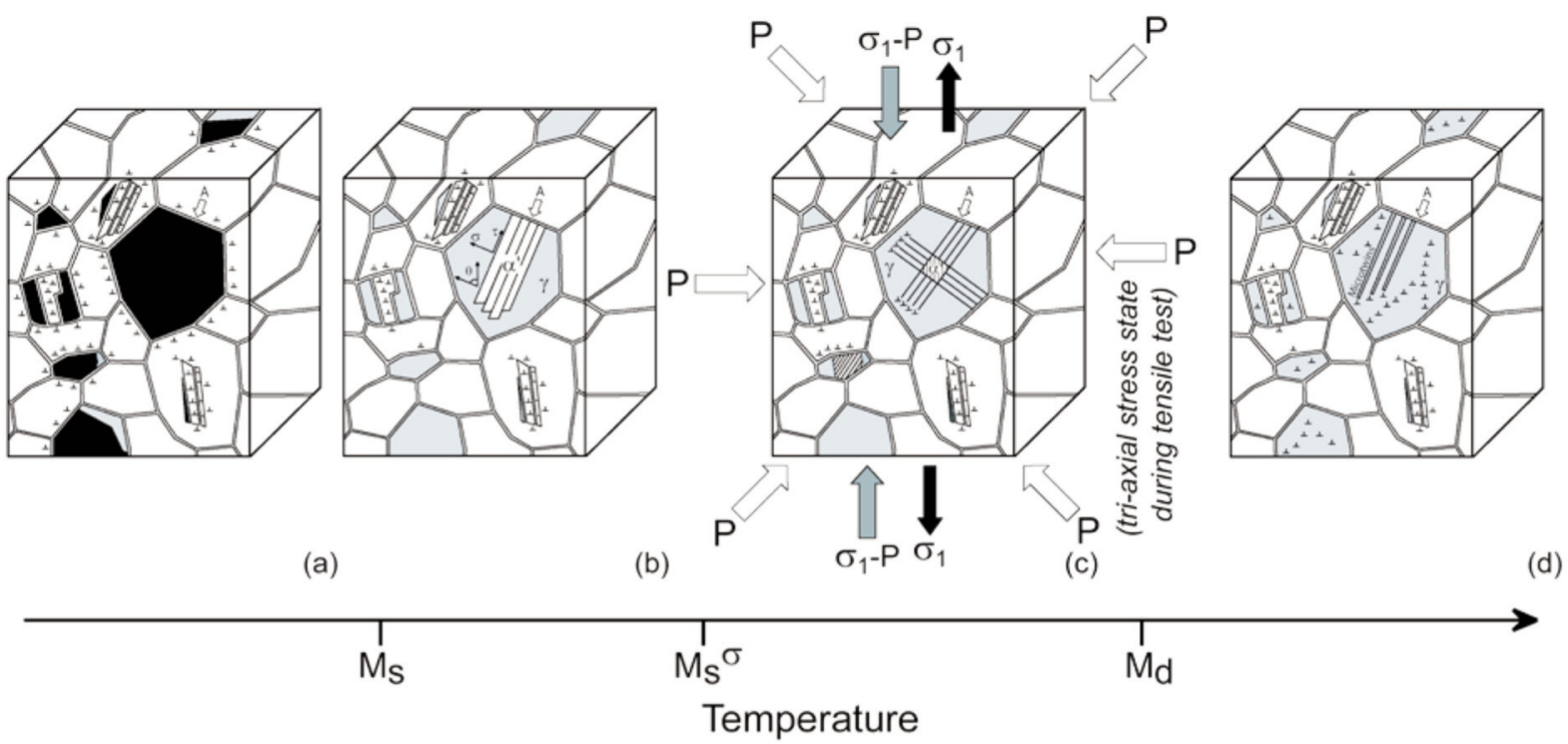

Polygonal ferrite

Retained austenite

Athermal martensite

Strain-induced martensite (after low straining at room temperature)

Bainitic ferrite (with high dislocation density)

Figure 10. Dominant deformation mechanisms in TRIP steel in different temperature ranges in a retained austenite grain indicated by the A-labelled arrow, i.e. formation of athermal martensite (a), stress-induced plasticity (b), strain-induced plasticity (c) and dislocation glide plasticity with microtwins formation (d). Additionally, (c) illustrates the triaxial stress state of a volume element subjected to strain-induced martensitic phase transformation during tensile test.

Figura 10. Mecanismos dominantes de deformación en diferentes rangos de temperatura en un grano de austenita revenida (indicado por la flecha etiquetada A) en acero TRIP: (a) formación de martensita atérmica, (b) plasticidad inducida por la tension, (c) plasticidad inducida por la deformación, y $(d)$ deslizamiento de dislocaciones con formación de microtwins. Además, (c) muestra el estado de tensión triaxial de un elemento de volumen sometido a una transformación de fase martensítica durante un ensayo de tensión. 

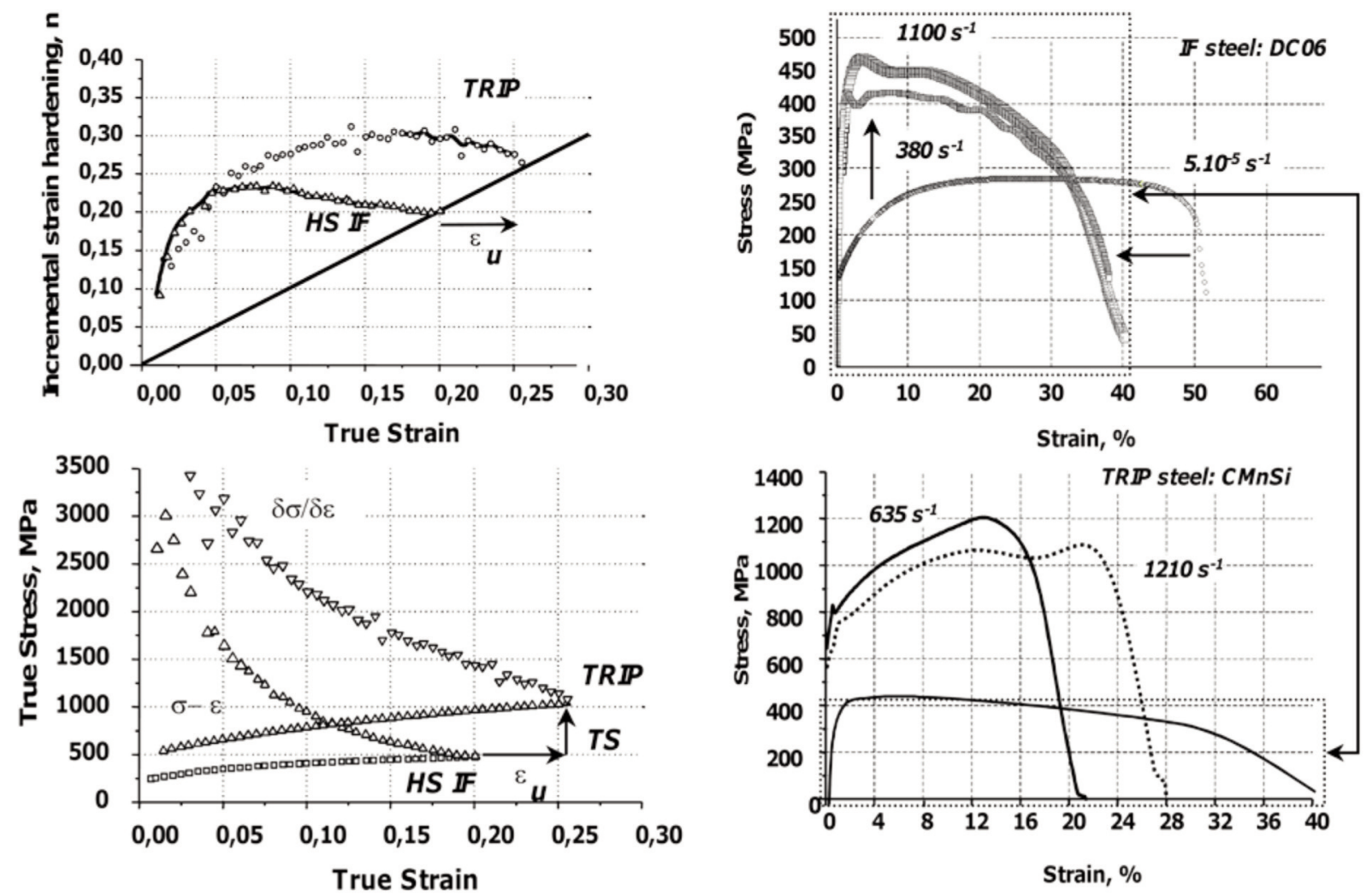

Figure 11. Comparison of static tensile properties of a high strength interstitial free steel (HS IF) and a low alloy TRIP-aided steel (left)- Comparison of the dynamic properties of an IF steel (right, above) and a TRIP-aided steel (right, below) ${ }^{[33]}$.

Figura 11. Comparación de las propiedades estáticas a tensión de un acero de alta resistencia libre de intersticiales (HS IF, por sus siglas en inglés) y un acero de baja aleación con efecto TRIP (izquierda)-Comparación de las propiedades dinámicas a tensión de un acero IF (derecha, arriba) y un acero con efecto TRIP (derecha, abajo)[33].

over the work hardening resulting from dislocation multiplication and dislocation intersection processes. As a consequence, the uniform elongation is very limited. In contrast, the flow stress of low alloy TRIP steel at the high strain rate is always higher than the flow stress observed at low strain rate. Both the strain hardening and the elongation are higher in dynamic, high strain rate, conditions.

TRIP steel is of great benefit for automotive applications for its energy absorption capacity in carcrash situations compared to the other advanced high strength steels. Figure 12 compares the energy absorption as a function of the tensile strength for dual phase steel, TRIP steel, bainitic steel, low carbon steel, and structural steel. TRIP steel offers the great advantage of having constant energy absorption as the strain rate increases, from quasi-static up to very high strain rate. The energy absorbed during the entire test is calculated as the area below the entire stressstrain curve. The resulting energy can then be plotted as a function of strain rate to evaluate the effectiveness

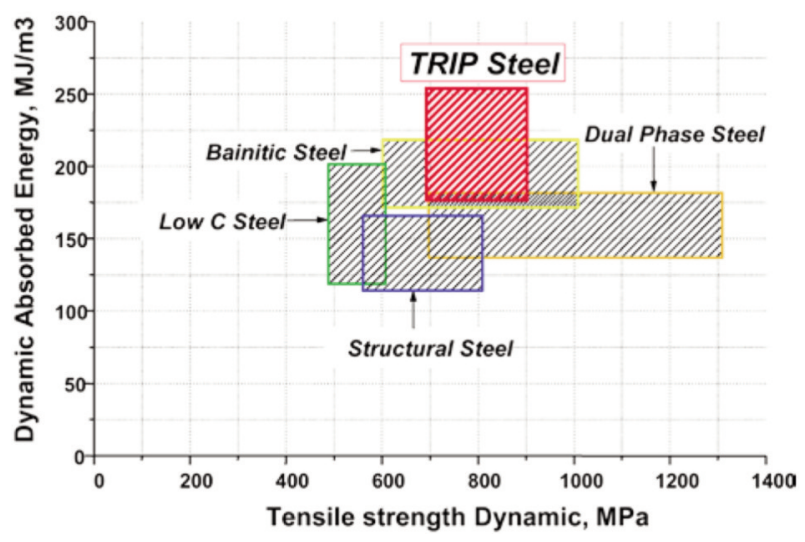

Figure 12. Dynamic absorbed energy versus dynamic tensile strength for dual phase steel, TRIP steel, bainitic steel, low carbon steel and structural steel.

Figura 12. Energía dinámica absorbida en función de la resistencia a tensión para aceros de fase dual, TRIP, bainíticos, con bajo contenido de carbono y acero estructural. 
ADVANCED HIGH STRENGTH STEELS FOR AUTOMOTIVE INDUSTRY ACEROS AVANZADOS DE ALTA RESISTENCIA EN LA INDUSTRIA AUTOMOVILISTICA

of the TRIP steels in absorbing energy during dynamic tests. The dynamic absorbed energy data up to a strain of $5 \%, 10 \%$, and 20 can be used for the calculations.
Figure 13 schematically shows the car manufacture process, starting with a sheet and finishing with crash testing. The figure illustrates the key role of TRIP
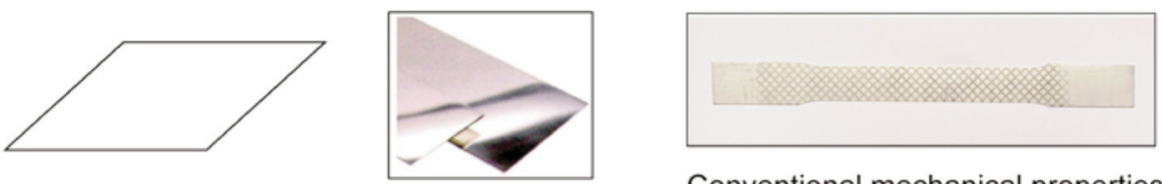

Conventional mechanical properties

Steel sheet (intercritical annealing, temper rolling)<smiles>C1CCCC1</smiles>
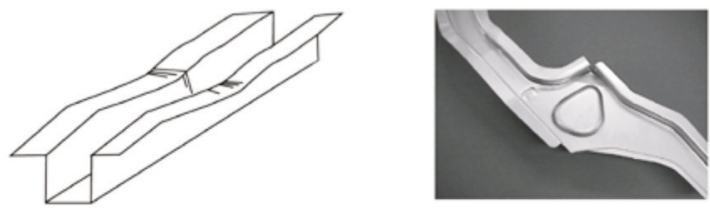

Forming, prestraining (pressed part)<smiles>C1CCCC1</smiles>
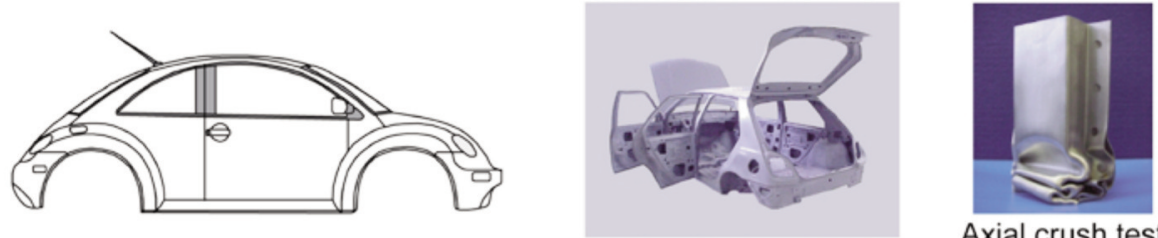

Axial crush test

Joining, bake-hardening (paint-baking)

Low temperature static strain ageing

Forming: springback

Welding: post-heating
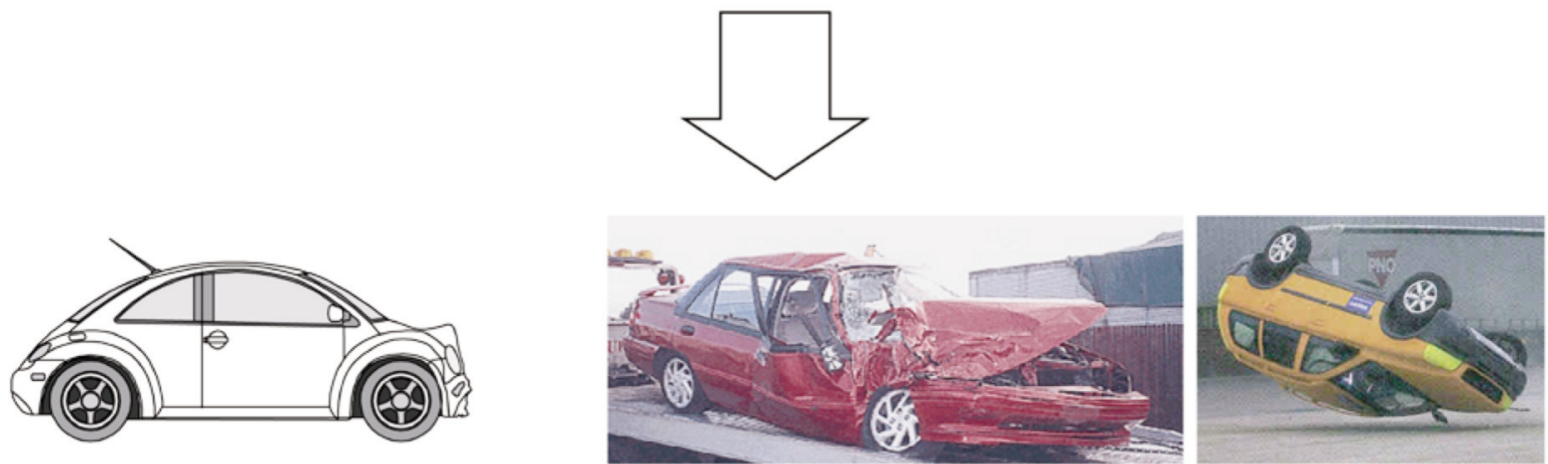

Crash testing: High strain rate deformation $\left(\sim 1000-2000 \mathrm{~s}^{-1}\right)$

\section{Complex strain}

Complex strain rate

Normalised crash tests:

- European NCAP

- North American NHTSA

Figure 13. Life of a carbody from the initial steel sheet to final crash testing.

Figure 13. Vida de una carrocería de coche desde la plancha de acero inicial hasta el ensayo de choque. 
steel to guarantee safety during crashes, because of a superior bake hardening response and superior mechanical properties at high strain rate ${ }^{[48]}$.

\section{CONCLUSIONS}

- The automotive industry faces the challenge of improving the fuel efficiency whilst ensuring crash safety. The materials used in the carbody offer the highest potential for improvement. High strength steels, ultra high strength steels and advanced high strength steels have been specifically developed by the steel industry to fulfil the demands of the car industry. These steels can provide the required mechanical properties at low cost and with a low environmental impact. TRIP steel is the first choice material for superior crash behaviour, thanks to its higher absorption of energy at dynamic strain rates.

\section{REFERENCES}

[1] G. Cole, A. Glove, R. Jeryan, and G. Davies, Steel World 2 (1997) 75-83.

[2] A. Jambor and M. Beyer, Mater. Des. 18 (1997) 203-209.

[3] J.L. Bast and J. Lehr, Heartland Policy Study 95 (2000) 1-69.

[4] J. Dargay and D. Gately, Transport. Res. a Pol. 33 (1999) 101-138.

[5] T. P. Wenzel and M. Ross, Accident Analysis and Prevention 37 (2005) 479-494.

[6] T. Klein, E. Hertz, and S. Borener, A collection of recent analyses of vehicle weight and safety, NHTSA DOT-HS-807 677, Washington, USA, 1991, pp. 1-23.

[7] Board on Energy and Environmental Systems, Effectiveness and Impact of Corporate Average Fuel Economy (CAFE) Standards, National Academy Press, Washington, USA, 2002, 184.

[8] W.C. Philips, Technische Mitteilungen ThyssenKrupp 4 (1999) 13-19.

[9] V. Flaxa and J. Shaw, Steel Grips 1 (2003) 255-261.

[10] B. Zuidema, S. Denner, B. Engl and JO. Sperle, SAE Techn. 42 (2001) 984-992.

[11] V.F. Zackay, D. Parker, D. Fahr, and R. Bush, Trans. ASM 60 (1967) 252-259.

[12] L. Barbe, K. Verbeken and W. Emiel, ISIJ Int. 46 (2006) 1251-1257.

[13] J. Bouquerel, K. Verbeken, D. Krizan et al, Steel Res 79 (2008) 784-792
[14] B. Engl, T. Heller, and R. Kawalla, Technische Mitteilungen ThyssenKrupp 4 (1999) 20-25.

[15] P. Sriram, J. G. Speer, and D. K. Matlock, SAE Techn. paper, 25 (1999) 184-187.

[16] G. Vaubel, Stahl Eisen 117 (1997) 45-48.

[17] W. Bleck, Proc. Int. Conf. on TRIP-Aided High Strength Ferrous Alloys, B.C. De Cooman (Ed.), Wissenschaftsverlag Mainz Gmbh, Ghent, Belgium, 2002, pp. 13-23.

[18] F.P. Pleschiutschnigg, V.V. Jamnis, S.R. Talwar, A.K. Misra, R.P.V. Atluri, R.B. Singh, P. Shankar, R.K. Verma, R.K. Goyal, V.P. Mishra, B. Deepu, P. Meierling, and J. Pleschiutschnigg, Steel Grips 2 (2004) 171-176.

[19] E. Doege, S. Kulp, and C. Sunderkotter, Steel Res. 73 (2002) 303-308.

[20] T. Waterschoot, B. C. De Cooman, A. K. De and S. Vandeputte, Metall. Mater. Trans. A 34A (2003) 781-791.

[21] K. Sugimoto, M. Kobayashi, and S. Hashimoto, Metall. Mater. Trans. A 23 (1992) 3085-3091.

[22] K. Sugimoto, A. Nagasaka, M. Kobayashi, and S. Hashimoto, ISIJ Int. 39 (1999) 56-63.

[23] K. Sugimoto, M. Kobayashi, A. Nagasaka, and S. Hashimoto, ISIJ Int. 35 (1995) 1407-1414.

[24] O. Matsumura, Y. Sakuma, Y. Ishii, and J. Zhao, ISIJ Int. 32 (1992) 1110-1116.

[25] K. Sugimoto, M. Misu, M. Kobayashi, and H. Shirasawa, ISIJ Int. 33 (1993) 775-782.

[26] G. N. Haidemenopoulos, M. Grujicic, G. B. Olson, and M. Cohen, J. Alloy Compd. 220 (1995) 142-147.

[27] N. Murai, and T. Tsumura, J. Iron Steel I. 84 (1998) 446-451.

[28] O. Matsumura, Y. Sakuma, and H. Takechi, Trans. Iron Steel Inst. 27 (1987) 570-579.

[29] Y. Sakuma, O. Matsumura, and H. Takechi, Metall. Mater. Trans. A 22 (1991) 489-498.

[30] K. Sugimoto, N. Usui, M. Kobayashi, and S. Hashimoto, ISIJ Int. 32 (1992) 1311-1318.

[31] P. J. Jacques, Curr. Opin. Solid St. M. 8 (2004) 259-265.

[32] L. Samek, B. De Cooman, J. Van Slycken, P. Verleysen, and J. Degrieck, Proc. $6^{\text {th }}$ Mesomechanics, Patras, Greece, 2004, G.C. Sih, Th. B. Kermanidis, SP. G. Pantelakis (Eds.), Elsevier, USA, 2004, pp. 120-128.

[33] L. Samek, B.C. De Cooman, J. Van Slycken, P. Verleysen, and J. Degrieck, Steel Res. Int. 75 (2004) 716-723.

[34] L. Samek, B.C. De Cooman, J. Van Slycken, P. Verleysen, and J. Degrieck, Proc. Int. Symp. on Transformation and Deformation Mechanisms in Advanced High-Strength Steels, Vancouver, 
ADVANCED HIGH STRENGTH STEELS FOR AUTOMOTIVE INDUSTRY ACEROS AVANZADOS DE ALTA RESISTENCIA EN LA INDUSTRIA AUTOMOVILISTICA

Canada, M. Militzer W.J. Poole, E. Essadiqi (Eds.) 2003, pp. 77-91.

[35] J. Van Slycken, J. Bouquerel, P. Verleysen, K. Verbeken, J. Degrieck and Y. Houbaert, Proc. $6^{\text {th }}$ Int. Conference on Processing and Manufacturing of Advanced Materials, Mater. Sci. Forum 638-642, Germany, 2009, T.Chandra, N.Wanderka, W.Reimers , M.Ionescu (Eds) Trans Tech Publications, Germany, 2010, pp. 3585-3590.

[36] R. Bode, M. Meurer, T. W. Schaumann, and W. Warnecke, Stahl Eisen 124 (2004) S19-S24.

[37] Y. Sakuma, D. K. Matlock, and G. Krauss, Metall. Mater. Trans. A (1992) 1221-1232.

[38] P. Jacques, X. Cornet, P. Harlet, J. Ladriere, and F. Delannay, Metall. Mater. Trans. A 29 (1998) 2383-2393.

[39] D.C. Ludwingson, and J.A. Berger, J. Iron Steel I. 207 (1969) 63-69.

[40] G.B. Olson, and M. Cohen, Metall. Mater. Trans. A 6A (1975) 791-795.

[41] G. B. Olson, and M. Azrin, Metall. Mater. Trans. A 9 (1978) 713-721.
[42] J. G. Speer, F. C. Rizzo -Assunção, D. K. Matlock, and D. V. Edmonds, Mat. Res. 8 (2005) 417-423.

[43] M. Santofimia, L. Zhao, and J. Sietsma, Metall. Mater. Trans. A 42 (2011) 3620-3626.

[44] L. Wang, and W. Feng, SAE Techn. paper, 439 (2010) 984-982.

[45] A. Wasilkowska, P. Tsipouridis, E. A. Werner, A. Pichler, and S. Traint, J. Mater. Process. Tech. 58 (2004) 633-636.

[46] H.H. Zou, L. Li, R.-Y. Fu, B.C. De Cooman, P. Wollants, X.-D. Zhu, and L. Wang, Proc. Int. Conf. on TRIP-Aided High Strength Ferrous Alloys, B.C. De Cooman (Ed.), Ghent, Belgium, 2002, pp. 317-320.

[47] J. Mahieu, J. Maki, B. C. De Cooman, and S. Claessens, Metall. Mater. Trans. A 33 (2002) 2573-2580.

[48] K. Sugimoto and M. Kobayashi, Proc. Symp. High Strength Steels for Automotive Industry, 36th MWSP, Baltimore, MD, EE.UU. 1994, pp. 255-65.

[49] L. Samek, E. De Moor, J. Penning, and B. C. De Cooman, Metall. Mater. Trans. A 37A (2006) 109-124. 